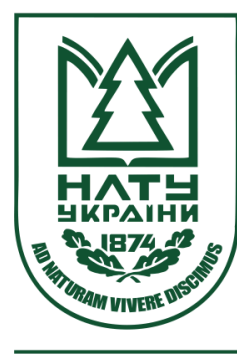

Науковий вісник НЛТУ України Scientific Bulletin of UNFU

http://nv.nltu.edu.ua

https://doi.org/10.15421/40280411

$@ \bowtie$ Correspondence author

Article received 22.03.2018 p.

Article accepted 26.04.2018 p.

I. N. Zhezhkun

УДК 630X73: 630X75

I. М. Жежкун

Український НДІ лісового господарства і агромеліорації ім. Г. М. Висоиького, м. Харків, Україна

\title{
ВСТАНОВЛЕННЯ РИНКОВИХ ЦІН НА НЕОБРОБЛЕНУ ДЕРЕВИНУ
}

В Україні обсяги використання деревного ресурсу щорічно збільшуються, частину якого на суму понад 1 млрд дол. США експортують за кордон. Вигідність експортування круглого лісу зумовлена ціновою різницею на $30-40 \%$ на внутрішньому та зовнішньому ринках. На сучасному етапі розвитку країни не вдалось реалізувати напрями державної цінової політики зі забезпечення збалансованості ринку необробленої деревини та запобігання зловживанню монопольним становищем у сфері ціноутворення на лісові ресурси. Для відродження вітчизняної деревообробної промисловості та стабілізації поставок деревної сировини на внутрішній ринок в Україні з 2017 р. строком на 10 років заборонено експорт необробленої деревини та дров паливних, завдовжки понад 2 м. В Україні тривають суперечки між лісогосподарської галуззю та галузями лісопромислового комплексу (ЛПК) щодо встановлення справедливого ринкового механізму ціноутворення та динаміки відпускних цін на необроблену деревину. Останніми роками загострились суперечності між великим і дрібним вітчизняним бізнесом деревообробної галузі щодо рівних можливостей закупівель необхідних обсягів деревної сировини та встановлення прийнятних ринкових цін. Дискусійним залишається й питання економічної доцільності та правомірності фактичного керування з боку Держлісагентства України та регіональних органів управління лісогосподарської галуззю процесом встановлення цін на деревну сировину підвідомчих лісогосподарських підприємств. Наведено результати та доведено економічну ефективність для постійних лісокористувачів електронних дистанційних аукціонів з продажу необробленої деревини, проведених упродовж 2017 - I кварталу 2018 рр., порівняно з очними торгами. Визначено основні недоліки та проблеми ціноутворення на продукцію необробленої деревини, що виникають за умов іiї реалізації на усних аукціонах. Встановлено недосконалість дієвого в Україні механізму організації та проведення аукціонів з продажу необробленої деревини. Запропоновано заходи 3 поліпшення механізму проведення аукціонів та підходів до ціноутворення на продукцію необробленої деревини.

Ключові слова: лісове господарство; квартальні усні аукціони; дистанційні електронні аукціони; постійні лісокористувачі; підприємства деревообробних галузей.

Вступ. У лісах України, що належать до державної форми власності, проведення державної цінової політики покладено на центральні органи виконавчої влади: Міністерство аграрної політики та продовольства і Державне агентство лісових ресурсів України (Zakon Ukrainy, 2012; Postanova Kabinetu Ministriv Ukrainy, 2014). Однак на сучасному етапі розвитку країни не вдалось реалізувати напрями державної цінової політики з забезпечення збалансованості ринку необробленої деревини та протидії зловживанню монопольним становищем у сфері ціноутворення на лісові ресурси (Zakon Ukrainy, 2012).

Упродовж останніх (2012-2016) років обсяги заготівлі ліквідної деревини в Україні стабільно зростали (на $1,7-5,1 \%$ ). За зазначений період загальне збільшення обсягів становило $12,0 \%$ (від 17 млн 506,7 тис. м ${ }^{3}$ до 19 млн 605,7 тис. м ${ }^{3}$ ) або в середньому $-4,0 \%$ на рік (Zahotivlia likvidnoi derevyny, 2017). Частину деревини у круглому вигляді та виробів первинної деревообробки експортували за кордон на суму понад 1 млрд дол. США на рік (2014 р. - 1262,0 млн дол., 2015 р. - 1107,2 млн дол., 2016 р. - 1131,6 млн дол.) (Zovnishnia torhivlia Ukrainy, 2017). Вигідність експорту для лісогосподарсь- ких та деревообробних підприємств-експортерів необробленої деревини та виробів 3 неї зумовлена вищими на 30-40\% цінами, що склалися за кордоном, ніж на внутрішньому ринку (Sopushynskyi et al., 2014). На вимогу екологів та підприємств галузей ЛПК, котрі наголошували на "знелісненні" країни та дефіциті деревної сировини на внутрішньому ринку, в Україні строком на 10 років введено заборону на експорт лісоматеріалів необроблених деревних порід, окрім сосни - 11 листопада 2015 p.; а сосни - 31 січня 2017 p. (Zakon Ukrainy, 2006). Прийняття поправок до Закону від 09.04.2015 p. (Zakon Ukrainy, 2006) на тимчасову заборону експорту необробленої деревини мало стабілізувати ціни на круглий ліс у країні та сприяти відродженню крупної деревообробної промисловості. Щоб унеможливити вивезення за кордон пиловнику під виглядом дров паливних, Держлісагентством України видано Наказ № 12 від 12.01.2017 p. (Nakaz ahentstva, 2017) щодо обмеження ix довжини (до 2 м) у разі поставки за межі країни.

Постановка проблеми. Ціна - це виражений у грошовій формі еквівалент одиниці товару (Zakon Ukrainy, 2012). Вона формується та встановлюється на відповідний товар або послугу на підставі попиту, вартості,

Інформація про авторів:

Жежкун Ірина Миколаївна, канд. екон. наук, ст. наук. співробітник лабораторії економіки і організації лісового господарства. Email: zhezhkun.iruna@gmail.com

Цитування за Дсту: Жежкун І. М. Встановлення ринкових цін на необроблену деревину. Науковий вісник НлтУ України. Серія Економічна. 2018, т. 28, № 4. С. 63-68

Citation APA: Zhezhkun, I. M. (2018). To the Question of Establishing Market Prices for Untreated Wood. Scientific Bulletin of UNFU, 28(4), 63-68. https://doi.org/10.15421/40280411 
пропозиції та товарно-грошового обігу (Tsinoutvorennia). Законом (Zakon Ukrainy, 2012) в Україні встановлено всього 2 види цін: вільні, що формують суб'єкти господарювання, та державні регульовані, на рівень котрих так чи інакше впливають відповідні державні органи.

Згідно зі Законом (Zakon Ukrainy, 2012) ціни на необроблену деревину мають бути вільними, тобто ринковими, утвореними на основі взаємодії попиту та пропозиції, які складаються під час аукціонів. До того ж Законом України "Про захист економічної конкуренції" (Zakon Ukrainy, 2001) сприяти розвитку конкуренції та не вчиняти будь-яких дій, що можуть негативно впливати на конкуренцію, зобов'язуються не тільки суб'єкти господарювання, а й органи влади та управління. Проте останнім часом спостерігається тенденція щодо збільшення впливу центральних та регіональних органів управління лісового господарства на формування та динаміку цін на круглий ліс. Так, до проекту "Стратегії реформування лісового господарства на період до 2030 року" (Proekt KMU, 2018) внесено положення щодо продажу необробленої деревини через аукціони, стартові ціни на котру встановлюються державним органом у сфері лісового господарства, і є обов'язковими для виконання лісокористувачами всіх форм власності. Тобто це положення прямо запроваджує централізацію встановлення мінімальних цін на круглий ліс та монополізує ринок деревини з боку власника лісових ресурсів, поширюючись на лісові ресурси не тільки підприємств, підпорядкованих Держлісагентству України, а й інших відомств. Отже, функції, які виконує Держлісагентство України щодо формування цін на деревину підвідомчих підприємств, не узгоджуються з антимонопольним законодавством (Zakon Ukrainy, 2000; Zakon Ukrainy, 2001), не відповідають напрямам державної цінової політики щодо протидії зловживанню монопольним (домінантним) становищем у сфері ціноутворення (Zakon Ukrainy, 2012), а призводить до економічно невиправданого завищення стартових цін аукціонів (Sahal, 2014) та розбалансованості внутрішнього ринку деревини. Напрям державної цінової політики щодо орієнтування цін внутрішнього ринку товарів на рівень світового ринку (Zakon Ukrainy, 2012) неможливо наразі реалізувати на ринку необробленої деревини через істотне відставання України за станом економічного розвитку від країн Свропейського Союзу.

Інша проблема, що виникає у ціноутворенні під час аукціонів та змінює результати у напрямку заниження цін, спричиняється змовою потенційних покупців деревини до початку торгів щодо розподілу лотів для їх придбання за стартовими (мінімальними) цінами. Відкритість інформації аукціонних торгів в умовах заздалегідь сформованого стабільного ринку покупців (лісопереробних підприємств) дає змогу останнім у багатьох випадках здійснювати штучний розподіл заявлених на продаж лотів і в такий спосіб запобігати збільшенню ціни товару під час аукціонних торгів навіть за умови продажу дефіцитної продукції. Це обмежує механізм конкуренції та сприяє заниженню справедливих ринкових цін виставлених партій деревини.

Отже, практика проведення аукціонів із продажу необробленої деревини за порядком, запропонованим Наказом Держкомлісгоспу України (Nakaz komitetu, 2007), $\epsilon$ недосконалою та такою, що не відповідає сучасним реаліям економіки, не забезпечує встановлення справедливих ринкових цін на основну продукцію лісогосподарської галузі - круглий ліс та не задовольняє інтереси як держави - власника лісових деревних ресурсів, так і основних покупців необробленої деревини - приватних підприємств галузей ЛПК.

Аналіз останніх публікацій та досліджень. У країні існує постійний довготривалий конфлікт між лісогосподарською галуззю та приватним сектором - покупцями деревини щодо встановлення справедливих розмірів та динаміки цін на необроблену деревину (Sahal, 2014; Asotsiatsiia "Chernihivlisderevprom", 2016). Так, на думку фахівців асоціації "Чернігівлісдеревопром" (Asotsiatsiia "Chernihivlisderevprom", 2016), ринок деревини в Україні - це монопольний ринок продавців, на якому спостерігається ріст споживання, що перевищує пропозицію. Тому вони вважають назрілою потреба включити його до Закону України "Про природні монополії" (Zakon Ukrainy, 2000), що дасть змогу ефективніше застосовувати державне регулювання, зокрема, зрозумілого і передбачуваного коригування ціни на необроблену деревину для недопущення стрімкого їх росту (Asotsiatsiia "Chernihivlisderevprom", 2016). Але останнім часом також посилились і внутрішні суперечності у ЛПК країни між малим і середнім бізнесом та великими деревообробними компаніями за доступ до деревного ресурсу. Особливо це проявилося за підсумками інтернет-аукціонів із продажу необробленої деревини кінця 2017 р., коли відбувся стрімкий ріст цін без наступного фактичного викупу лотів переможцями торгів (великими потужними компаніями) (Sobolevskyi, 2018). Середні та малі підприємства деревообробної галузі справедливо вказують на недобросовісну конкуренцію (Zakon Ukrainy, 1996) та спробу "великих гравців" позбутись дрібних місцевих конкурентів. Проте структура підприємств галузей ЛПК України свідчить про переважання саме малих (87,6-94,3 \%) та мікропідприємств (64,9-75,5 \%) (таблиця).

Таблиця. Кількість та структура підприємств лісопромислового комплексу України за їх розмірами на 2016 р. (Diialnist velykykh, serednikh, malykh ta mikropidpryiemstv v promyslovosti, 2016)

\begin{tabular}{|c|c|c|c|c|c|c|}
\hline \multirow{2}{*}{$\begin{array}{c}\text { Розмір } \\
\text { під- } \\
\text { приємств }\end{array}$} & \multicolumn{6}{|c|}{ Кількість підприємств та їх структура } \\
\cline { 2 - 7 } & деревообробна & \multicolumn{2}{|c|}{ паперова } & \multicolumn{2}{|c|}{ меблева } \\
\cline { 2 - 7 } & шт. & $\%$ & Шт. & $\%$ & Шт. & $\%$ \\
\hline Великі & 3 & 0,1 & 3 & 0,3 & 1 & 0,1 \\
\hline Середні & 145 & 5,6 & 108 & 12,1 & 103 & 8,9 \\
\hline Малі: & 2440 & 94,3 & 782 & 87,6 & 1057 & 91,0 \\
\hline $\begin{array}{c}\text { 3 них } \\
\text { мікро- }\end{array}$ & 1954 & 75,5 & 580 & 64,9 & 825 & 71,0 \\
\hline Разом & 2588 & 100,0 & 893 & 100,0 & 1161 & 100,0 \\
\hline
\end{tabular}

Великі компанії (1-3 підприємства) з кількістю працівників понад 250 осіб та річним доходом понад 50 млн євро становлять у структурі галузей ЛПК держави менше $1 \%$, однак істотно впливають на розподіл деревної сировини в регіонах країни, викликаючи обурення місцевих дрібних підприємців (Dynka, 2017).

Отже, наявна практика реалізації деревної сировини не $\epsilon$ стабільною для лісогосподарських підприємств та створює ризики для функціонування галузей ЛПК країни.

За аналізом фахівців для забезпечення стабільності ціноутворення на необроблену деревину на внутрішньому ринку щорічні обсяги іiї перероблення в Ук- 
раїні мають становити 1-2 млн м ${ }^{3}$ (Sopushynskyi et al., 2014). Для забезпечення вітчизняних приватних деревообробних підприємств деревиною за справедливими ринковими цінами потрібні термінові заходи щодо удосконалення механізму продажу необробленої деревини через механізм аукціонів (Dynka, 2017; Kholiavka et al., 2011; Yatsyshyn et al., 2016). А. М. Половський (Polovskyi, 2012) пропонує в Україні застосовувати не тільки відкриті усні торги, але й закриті аукціони першої та другої цін, котрі ефективні для продавця в умовах низького попиту на сировину, тобто в умовах економічної кризи. Також автор вважає за можливе запровадити механізм реалізації через аукціони не тільки продукції - круглого лісу, а й прав користування - лісу на корені. Однак продаж лісу на корені не відповідає кінцевій меті лісовирощування - отримання лісогосподарськими підприємствами результатів їх діяльності продукції у вигляді стиглого лісу. Для максимізації доходів лісогосподарських підприємств С. М. Демидюк (2013) пропонує лібералізацію допуску до квартальних аукціонів всім охочим покупцям, зокрема, i підприємствам, що не мають власного деревообробного, плитного або фанерного виробництв, а також нерезидентам України. Проте, на нашу думку, це призведе до збільшення обсягів закупівлі деревини для подальшого iï перепродажу за вищими цінами та до обмеження доступу до сировини середнього та дрібного бізнесу, що $є$ небажаними явищами в економіці країни.

На обмеження конкуренції в ціноутворенні на необроблену деревину впливають також "привілеї" деревообробним цехам лісогосподарських підприємств, надані Наказом Держкомлісгоспу України № 42 від 19.02.2007 p. (Nakaz komitetu, 2007) щодо придбання ними деревної сировини в необхідних обсягах в обхід аукціонів та за собівартістю, а не ринковими цінами, встановленими на торгах (Demydiuk, 2013; Yatsyshyn et al., 2016). Вирішення цього питання потрібно розглядати у законодавчій площині через зобов'язання продавців необробленої деревини виставляти на квартальні аукціони весь обсяг ресурсу та можливості направляти на деревообробку у власні цеха тільки сировину лотів, не викуплених приватними покупцями під час торгів.

Інша радикальна точка зору науковців полягає не в удосконаленні, а в скасуванні періодичних квартальних торгів необробленої деревиною та переходу до практики регулярних (постійних) біржових торгів через посередників - брокерів (Androsovych, 2014; Hoichuk, 2012; Datsko, 2010; Demydiuk, 2013) та встановленні ринкових цін на необроблену деревину через біржові котирування. Однак ця проблема може бути вирішена механізмом додаткових аукціонів, котрі проводитимусь частіше, ніж раз на квартал (1 раз на місяць, декаду, тиждень тощо). Така практика вже існує, наприклад, під час проведення торгів необробленою деревиною на Аграрній біржі (Ahrarna birzha, 2017). Для запобігання практиці "зриву" основних аукціонів за окремими лотами 3 метою придбання дефіцитних матеріалів на додаткових за більш прийнятними для покупців цінами необхідно запровадити процедуру введення на них стартових цін, що утворились на подібні лоти за підсумками основного аукціону.

Ще одна група фахівців покращенням механізму реалізації необробленої деревини через аукціони з метою підвищення їх результативності для постійних лісоко- ристувачів, завдяки запобіганню попередньої змови покупців, бачить електронні (дистанційні) торги без їх очної участі під час проведення (Androsovych, 2014; Yatsyshyn et al., 2016). Електронні дистанційні аукціони виявились порівняно економічно ефективнішими для продавців деревини, ніж усні. Так, за даними Чернігівського регіону (Східне Полісся) (Chernihivskyi rehion, 2017) у першому кварталі 2018 р. лісогосподарські підприємства на Аграрній біржі виставили на електронні торги $102168 \mathrm{~m}^{3}$ деревини хвойних і листяних порід, з яких було продано 96,7 \% (98784 м³) на загальну суму 142 млн 764 тис. 454 грн. Приріст цін реалізації, порівняно зі стартовими, становив 28,7\% (або 40 млн 706 тис. грн). У попередньому IV кварталі 2017 р. на електронних торгах стартова вартість лотів деревини становила 107 млн 550 тис. 829 грн, а кінцева - на 15,21\% більше (на 16 млн 358 тис. грн). На відміну від електронних торгів, динаміка збільшення стартової ціни на усних аукціонах становила - 3,5 \%, тобто кінцева ціна реалізації лотів була меншою за стартову (Chernihivskyi rehion, 2017). За електронних торгів виявилась й позитивна динаміка щодо кількості потенційних покупців деревини: так, у Чернігівській обл. в аукціоні з продажу ресурсу ріст їх кількості у першому кварталі 2018 р., порівняно 3 попереднім, становив 14,1 \% (219 проти 192) (Chernihivskyi rehion, 2017). Загалом в Україні за підсумками електронних аукціонів 3 продажу необробленої деревини, що відбувалися за участю лісогосподарських підприємств 10 областей (Київської, Чернігівської, Харківської, Сумської, Рівненської, Кіровоградської, Тернопільської, Одеської, Донецької та Луганської) на майданчику Аграрної біржі, тільки за IV квартал 2017 р. держава додатково отримала 74,2 млн грн, а за результатами III і IV кварталів - 118, 674 млн грн. В електронних аукціонах брали участь 857 представників переробних підприємств 310 регіонів України (Ahrarna birzha, 2017). Враховуючи позитивні для лісогосподарської галузі та бюджету країни підсумки електронних аукціонів 3 продажу необробленої деревини, що були проведені впродовж 2017 р., Держлісагентством України (Nakaz ahentstva, 2018) планується забезпечити збільшення обсягів реалізації необробленої деревини на аукціонних торгах 3 використанням електронних торгових систем та реалізувати на них понаднормові залишки деревини, що знаходяться на складах. Проте, варто зазначити, що істотне підвищення аукціонних цін на необроблену деревину, порівняно зі стартовими цінами, може призвести до відмови переможців аукціону купувати виграні лоти.

3-поміж науковців поширена думка, що для встановлення справедливих ринкових цін на продукцію необробленої деревини варто законодавчо зобов'язати іiі реалізацію на конкурсних засадах для всіх постійних лісокористувачів (Мінагрополітики, Міноборони тощо), а не тільки для підприємств, підпорядкованих Держлісагентству України (Datsko, 2010). С. Сагаль (Sahal, 2014) наполягає на необхідності розроблення та упровадження дієвого та прозорого механізму формування стартових цін аукціонів на необроблену деревину, який запобігав би їх необгрунтованому збільшенню з боку продавців.

Важливою проблемою у проведенні квартальних аукціонів 3 реалізації необробленої деревин залишається закупівля до 30-40 \% сировини перекупщика- 
ми, що забирають його у реальних виробників (Asotsiatsiia "Chernihivlisderevprom", 2016). Цю проблему мають вирішити аукціонні комітети бірж методом їх недопущення до аукціонів на підставі аналізу попередніх торгів та запровадження проти них фінансових санкцій.

Для гарантування забезпечення місцевих малих підприємств деревообробної галузі деревною сировиною лунають пропозиції щодо удосконалення механізму іiі реалізації на аукціонах через поділ загальних обсягів для місцевих покупців та покупців з інших регіонів у співідношенні $50 \times 50 \%$ (Asotsiatsiia "Chernihivlisderevprom", 2016) або 70×30\% (Zaprovadzhennia poriadku, 2017). Тобто пропонують проводити основні аукціоні в 2 етапи: у перший день виставляти обумовлену частку квартального обсягу необробленої деревини для місцевих покупців та на другій - частку, встановлену для великих гравців та не викуплену у першій день сировину підприємствами малого та середнього бізнесу. Відповідно до виробничої потужності покупців доцільно формувати й обсяги лотів (Diachyshyn et al., 2011): для дрібних покупців - 10-20 м³ для середнього бізнесу $25-100 \mathrm{~m}^{3}$, для найбільш крупних виробників $-200 \mathrm{~m}^{3} \mathrm{i}$ більше.

\section{Висновки}

1. Чинне Положення "Про порядок реалізації необробленої деревини", затверджене Наказом Держкомлісгоспу України № 42 від 19.02.2007 p. (Nakaz komitetu, 2007), а також дієва на цей час нормативно-правова база, не стимулюють розвиток малого та середнього бізнесу ЛПК країни, призводять до фактів перепродажу деревини, монополізації ринку купівлі необробленої деревини потужними деревопереробними підприємствами, дестабілізують процес ринкового ціноутворення на сортименти круглого лісу.

2. Для приведення нормативно-правової бази у сфері реалізації необробленої деревини до вимог сучасного стану економіки країни, підвищення ефективності аукціонних торгів завдяки забезпеченню справедливого ринкового ціноутворення та припинення конфлікту в забезпеченні сировиною підприємств ЛПК різної виробничої потужності та регіональної приналежності запропоновано:

- законодавчо зобов'язати здійснювати реалізацію необробленої деревини у країні через ринкові механізми аукціонів для всіх постійних лісокористувачів незалежно від їх відомчого підпорядкування;

- для забезпечення справедливих умов конкуренції за сировину між деревообробними цехами лісогосподарських підприємств постійних лісокористувачів та приватними деревообробними структурами законодавчо зобов'язати перших отримувати для власних виробничих потреб тільки необроблену деревину, що за підсумками аукціонів не була затребувана покупцями - підприємствами галузей ЛПК;

- з метою встановлення прозорого механізму ціноутворення під час формування стартових цін аукціонів на необроблену деревину та запобігання своєвільному втручанню в цей процес керівних органів розробити та законодавчо затвердити методику розрахунку встановлення та динаміки стартових цін на сортименти необробленої деревини для постійних лісокористувачів - лісогосподарських підприємств, які виставляють деревину на аукціони;

- передбачити можливість для постійних лісокористувачів лісогосподарських підприємств реалізовувати необроблену деревину залежно від поточної економічної ситуації через різні види аукціонів (електронні дистанційні; відкриті усні; закриті першої та другої ціни тощо) без втручання у процеси вибору видів аукціонів на деревину керівних відомчих органів. Під час вибору виду аукціону на відповідний квартал лісогосподарські підприємства мають враховуватись тільки економічні чинники, тобто найвища очікувана ефек- тивність (прибутковість) за максимальних фізичних обсягів реалізації деревини;

- для запобігання монополізації ринку необробленої деревини крупними покупцями проводити щоквартальні загальні аукціонні торги через регіональні (обласні) товарні біржі у дві сесії: у першу - реалізовувати необроблену деревину для місцевих дрібних деревообробних підприємств у встановленому залежно від їх кількості та сумарної виробничої потужності обсязі (50-70 \%), у другу - для всіх суб'єктів господарювання - резидентів України, що мають деревообробне виробництво в обсягах (50-30 \%) та з урахуванням нереалізованого обсягу лісоматеріалів під час першої торгової ceciï;

- для недопущення до аукціонів перекупщиків деревини запровадити у регламентах товарних бірж перед допуском до торгів механізму перевірки та у разі потребу підтвердження наявності у потенційних покупців виробничих потужностей, механізмів та обладнання, необхідних для перероблення необробленої деревини в заявлених обсягах покупки сировини;

- передбачити у регламентах товарних бірж санкції у вигляді недопущення впродовж певного періоду до наступних аукціонів у відношенні недобросовісних покупців у разі порушення ними умов придбання на торгах деревини (не підписання договору купівлі - продажу при виграші на аукціоні, не отримання купленої деревини, постійного "зриву" реалізації лотів).

\section{Перелік використаних джерел}

Ahrarna birzha. (2017). Ahrarna birzha rozpochynaie elektronni auktsiony z prodazhu neobroblenoi derevyny zahotivli I kvartalu 2018 r. Retrieved from: http://www. agronews.ua/node/84516. [In Ukrainian].

Androsovych, T. Yu. (2014). Birzhovi torhy neobroblenoiu derevynoiu - perspektyva rozvytku rynku lisomaterialiv [Stock trades by untreated wood - prospects of market timber development]. Visn. KrNU im. M. Ostrohradskoho. Ser. Bukh. oblik, finansy ta hroshovyi obih, 6(89) part 2, 111-115. [In Ukrainian].

Asotsiatsiia "Chernihivlisderevprom". (2016). Lisnyky vs moratorii 1:0? [Foresters vs moratorium - 1:0?]. Retrieved from: http://chldp.com.ua/2016/ 12/01/lisnyky-vs-moratorij/. [In Ukrainian].

Chernihivskyi rehion. (2017). Chernihivskyi rehion uspishno proviv auktsion z prodazhu neobroblenoi derevyny resursu I kvartalu 2018 roku. Retrieved from: http://strichka.com/item/72111063. [In Ukrainian].

Datsko, S. Ya. (2010). Analiz konkursnoho prodazhu neobroblenoi derevyny pidpryiemstvamy Lvivskoho OULMH. [An analysis of competitive sale of untilled wood by the enterprises of the Lviv regional management of forest and hunting economy]. Scientific Bulletin of UNFU, 20(11), 132-138. [In Ukrainian].

Demydiuk, S. M. (2013). Rehuliuvannia realizatsii neobroblenoi derevyny $\mathrm{v}$ Ukraini. [Regulation of realization of unprocessed wood in Ukraine]. Ahrosvit, 21, 40-45. [In Ukrainian].

Diachyshyn, O. V., \& Martyniuk, N. O. (2011). Doslidzhennia protsesu tsinoutvorennia na produktsiiu lisovoho pidpryiemstva. [Research of process of pricing on the products of forestry]. Scientific Bulletin of UNFU, 21(14), 199-205. [In Ukrainian].

Diialnist velykykh. (2016). Diialnist velykykh, serednikh, malykh ta mikropidpryiemstv v promyslovosti. Statystychnyi zbirnyk "Diialnist subiektiv velykoho, serednoho, maloho ta mikropidpryiemnytstva", 252-254. Retrieved from: http:/ukrstat.gov.ua/druk/ publicat/kat_u/2017/zb/12/zb_dsvm2016w.zip. [In Ukrainian].

Dynka, P. K. (2017). Reforming Forestry of Ukraine in the context of development of civil society. Scientific Bulletin of UNFU, 27(7), 913. https://doi.org/10.15421/40270701

Hoichuk, D. A. (2012). Birzhova torhivlia yak mekhanizm realizatsii neobroblenoi derevyny v Ukraini. [Exchange trade as a mechanism for the implementation of untreated timber in Ukraine]. Visn. Dnipropetr. Derzh. Ahrarn. Univ. 2, 196-199. [In Ukrainian].

Kholiavka, V. Z., \& Datsko, S. Ya. (2011). Zastosuvannia auktsionnoi torhivli produktsiieiu lisovoho hospodarstva u svitli ekolohizatsii tsinovoi polityky Ukrainy. [Using the auction trade in forest pro- 
ducts in the light ecological pricing of Ukraine]. Scientific Bulletin of UNFU, 21(12), 269-274. [In Ukrainian].

Nakaz ahentstva. (2017). Deiaki pytannia eksportu lisomaterialiv neobroblenykh. Nakaz Derzhavnoho ahentstva lisovykh resursiv Ukrainy vid 12.01.2017 p., № 12. Retrieved from: http://dklg.kmu.gov.ua/forest/control/uk/publish/article?art_id $=175822 \&$ cat_id $=65319$. [In Ukrainian].

Nakaz ahentstva. (2018). Pro pidsumky hospodarsko-finansovoi diialnosti pidpryiemstv haluzi za 2017 rik. Nakaz Derzhavnoho ahentstva lisovykh resursiv Ukrainy vid 30.01 .1018 p., № 49. Retrieved from: http://klg.kmu.gov.ua/forest/control/uk/publish/article?art_id=189571\&cat_id =65319. [In Ukrainian].

Nakaz komitetu. (2007). Polozhennia pro orhanizatsiiu ta provedennia auktsioniv z prodazhu neobroblenoi derevyny. Nakaz Derzhavnoho komitetu lisovoho hospodarstva Ukrainy vid 19.02.2007 p., № 42. Retrieved from: http://zakon.rada.gov.ua/laws/show/z0164-07. [In Ukrainian].

Polovskyi, A. M. (2012). Analiz dosvidu SSHA shchodo prodazhu derevyny z derzhavnykh lisiv. [An analysis of the US experience in stumpage sales from State Forests]. Scientific Bulletin of UNFU, 22(12), 306-310. [In Ukrainian].

Postanova KMU. (2014). Pro zatverdzhennia Polozhennia pro Derzhavne ahentstvo lisovykh resursiv Ukrainy. Postanova Kabinetu Ministriv Ukrainy № 521 vid 3/10/2014 r. Retrieved from: http://www.kmu.gov.ua/ control/uk/newsnpd? npdList_stind=21. [In Ukrainian].

Proekt. (2018). Proekt rozporiadzhennia Kabinetu Ministriv Ukrainy "Pro skhvalennia Stratehii reformuvannia lisovoho hospodarstva na period do 2030 roku". [In Ukrainian].

Sahal, S. (2014). Analiz potentsialu lisovoho sektoru Ukrainy ta vyiavlennia faktoriv, shcho halmuiut yoho innovatsiinyi rozvytok. [Analysis of the potential of the Ukrainian forestry sector and the identification of factors hindering its innovative development]. Rehionalna prohrama "Pravozastosuvannia y upravlinnia v lisovomu sektori krain Skhidnoho rehionu. Dii yevropeiskoho instrumentu susidstva ta partnerstva". Retrieved from: http://www.enpifleg.org/.../report_sagal_forest_sector_potential.p.... [In Ukrainian].

Sobolevskyi, I. (2018). Zakhmarni tsiny na tli shtuchnoho defitsytu. [Sunset prices in the face of artificial shortage]. Retrieved from: www.galychyna.if.ua/.../ zakhmarni-cini-na-tli-shtuchnogo-d.... [In Ukrainian].

Sopushynskyi, I. M., Klym, N. M., \& Kharyton, I. I. (2014). Yevropeiskyi dosvid tsinoutvorennia na rynku kruhlykh lisomaterialiv khvo- inykh porid. [European experience of pricing in the market for roundwood of coniferous species]. Scientific Bulletin of UNFU, 24(10), 29-34. [In Ukrainian].

Tsinoutvorennia. (n.d.). Retrieved from: https://uk.wikipedia.org/wiki/Tsinoutvorennia. [In Ukrainian].

Yatsyshyn, M., \& Lys, O. (2016). Realizatsiia neobroblenoi derevyny na konkursnykh zasadakh: pravova komparatyvistyka ukrainskoho ta zarubizhnoho dosvidu. [Realization of raw wood on a competitive basis: legal comparative analysis of the Ukrainian and foreign experience]. Istoryko-pravovyi chasopys: nauk. zhurn. Skhidnoievrop. nats. universytet im. Lesi Ukrainky, 2(8), 112-115. [In Ukrainian].

Zahotivlia (2010). Zahotivlia likvidnoi derevyny. (2010-2016). Statystychni dani. Retrieved from: http:/ukrstat.gov.ua/operativ/operativ2017/sg/lis/zld/xls/zid_u.zip. [In Ukrainian].

Zakon Ukrainy. (1996). Pro zakhyst vid nedobrosovisnoi konkurentsii. Zakon Ukrainy vid 07.06.1996 p., № 236 / 96 - VR. Retrieved from: http://search. ligazakon.ua/1_doc2.nsf/link1/Z960236.html. [In Ukrainian].

Zakon Ukrainy. (2000). Pro pryrodni monopolii. Zakon Ukrainy vid 20.04.2000 p., № 1682-III. Retrieved from: http://zakon.rada.gov.ua/go/1682-14. [In Ukrainian].

Zakon Ukrainy. (2001). Pro zakhyst ekonomichnoi konkurentsii/ Zakon Ukrainy vid 11.01.2001 p., № 2210-III. Retrieved from: http://search.ligazakon.ua/__doc2.nsf/link1/T012210.html. [In Ukrainian].

Zakon Ukrainy. (2006). Pro osoblyvosti derzhavnoho rehuliuvannia diialnosti subiektiv pidpryiemnytskoi diialnosti, poviazanoi z realizatsiieiu ta eksportom lisomaterialiv. Zakon Ukrainy vid 08.09.2005 p., № 2860-IV. Retrieved from: http://search.ligazakon.ua/l doc2.nsf/link1/T052860.html. [In Ukrainian].

Zakon Ukrainy. (2012). Pro tsiny i tsinoutvorennia. Zakon Ukrainy vid 21.06.2012 p., № 5007-VI. Retrieved from: http://apteka.ua/article/154196. [In Ukrainian].

Zaprovadzhennia. (2017). Zaprovadzhennia novoho poriadku realizatsii neobroblenoi derevyny stymuliuvatyme rozvytok biznesu oblasti. Retrieved from: http:// zakarpat-rada.gov.ua/w-content/plugins/as-pdf/generate.php?post=54733. [In Ukrainian].

Zovnishnia torhivlia Ukrainy (2017). Statychnyi zbirnyk. Derzhavna sluzhba statystyky Ukrainy. Kyiv. Retrieved from: http://ukrstat.gov.ua/druk/publicat/kat_u/2017/zb/06/zb/ ZTU_2016x.zip. [In Ukrainian].

Украинский НИИ лесного хозяйства и агромелиорации им. Г. М. Высоикого, г. Харьков, Украин

\section{ОПРЕДЕЛЕНИЕ РЫНОЧНЫХ ЦЕН НА НЕОБРАБОТАННУЮ ДРЕВИСИНУ}

В Украине ежегодно увеличиваются объемы использования древесного ресурса, часть которого на сумму более 1 млрд дол. США экспортируется за границу. Выгодность экспорта круглого леса обусловлена ценовой разницей в $30-40 \%$ на внутреннем и внешнем рынках. На современном этапе развития страны не удалось реализовать направления государственной ценовой политики по обеспечению сбалансированности рынка необработанной древесины и предотвращение злоупотребления монопольным положением в сфере ценообразования на лесные ресурсы. С целью возрождения отечественной деревообрабатывающей промышленности и стабилизации поставок древесного сырья на внутренний рынок в Украине с 2017 г. сроком на 10 лет запрещен экспорт необработанной древесины и дров топливных, длиной более 2 м. В Украине продолжаются дискуссии между лесохозяйственной отраслью и отраслями лесопромышленного комплекса (ЛПК) по установлению справедливого рыночного механизма ценообразования и динамики отпускных цен на необработанную древесину. В последние годы обострились противоречия между большим и мелким отечественным бизнесом деревообрабатывающей отрасли относительно равных возможностей закупок необходимых объемов древесного сырья и установления приемлемых рыночных цен. Дискуссионным остается и вопрос экономической целесообразности и правомерности фактического управления со стороны Гослесагентства Украины и региональных органов управления лесохозяйственной отраслью процессом установления цен на древесное сырье подведомственных лесохозяйственных предприятий. Приведены результаты и доказана экономическая эффективность для постоянных лесопользователей электронных дистанционных аукционов по продаже необработанной древесины, проведенных в течение 2017 - I квартала 2018 гг., по сравнению с очными устными торгами. Определены основные недостатки и проблемы ценообразования на продукцию необработанной древесины, возникающие в условиях реализации на устных аукционах. Установлено несовершенство действующего в Украине механизма организации и проведения аукционов по продаже необработанной древесины. Предложены меры по улучшению механизма проведения аукционов и подходов к ценообразованию на продукцию необработанной древесины.

Ключевые слова: лесное хозяйство; квартальные устные аукционы; дистанционные электронные аукционы; постоянные лесопользователи; предприятия деревообрабатывающих отраслей. 


\section{TO THE QUESTION OF ESTABLISHING MARKET PRICES FOR UNTREATED WOOD}

In Ukraine, the question of establishing fair market prices for untreated wood remains problematic. The current mechanism of sale of untreated wood on commodity regional exchanges through quarterly auctions was introduced in 2007 . Consequently, the conditions of functioning of the forestry enterprises in the country have changed considerably since then: since 2017 it is forbidden to export round wood and firewood, more than $2 \mathrm{~m}$ in length for a 10 year period; in a way that is not regulated by law, electronic distant auctions for the sale of unprocessed timber are introduced. Together with changes in the sale of round wood, there is still the contradiction of interest between the forestry and private enterprises - round wood handlers for the influence on the formation of the level and dynamics of prices for round wood. Recently, contradictions between the small and large woodworking businesses of the country were also revealed due to the accessibility of wood resources and their unequal opportunities in price competition. As a result of the analysis of literary sources and actual statistical data from the investigated issues, the main drawbacks of the current mechanism for the sale of unprocessed wood through open oral auctions we identified and proposed measures to improve it in order to ensure the subsequent receipt of free market prices for round wood. Moreover, the recommended measures are based on the principle of maintaining a balance of interests when pricing the State Forestry and private forestry sector of the country's economy. As a result of the research carried out, the existing legal framework for the sale of untreated wood is modernized to the realities of the modern economic situation of the state.

Keywords: forestry; quarterly oral auctions; remote e-auctions; regular forest users; enterprises of woodworking industries. 